\title{
Individual and social determinants for the formation of identity: A comparative analysis of research strategies
}

\author{
E.D.Dryaeva ${ }^{1}$, I. A. Kanaev ${ }^{2}$ \\ ${ }^{1}$ Lomonosov Moscow State University, \\ 1, Leninskie Gory, Moscow, 119991, Russian Federation \\ 2 Sun Yat-sen University, \\ 135, Xingang Xi Rd, Guangzhou 510275, Guangdong, Peoples Republic of China
}

For citation: Dryaeva E. D., Kanaev I. A. Individual and social determinants for the formation of identity: A comparative analysis of research strategies. Vestnik of Saint Petersburg University. Philosophy and Conflict Studies, 2020, vol. 36, issue 4, pp. 621-633. https://doi.org/10.21638/spbu17.2020.402

This article investigates the concept of identity: the research objective is to consider the principles that can be used to unite various approaches to describing the emergence and transformation of human identity. The research method is a comparative analysis of significant theories of Western philosophy in terms of the achievements of modern interdisciplinary research. Within Western philosophy, most concepts of identity can be classified as belonging to individualcentric or socio-centric research models. Therefore, such a distinction serves as the starting point to discuss the emergence and transformation of the concept of identity. The provided analysis reveals two facts. First, the investigation starts either from individual human experience or from social communication structures, this choice determining further research as individual-centric or sociocentric. Second, it is ultimately impossible to reduce an individual experience or social effect to their opposition: both individual and social beings determine the emergence and functioning of human identity. Hence, human identity should be considered as a result of interaction between individual and social beings. Within contemporary epistemology, the activity realism approach provides a theoretical foundation for explaining identity as an outcome of human active cognition and the transformation of the environment. Thus, this article provides a theoretical foundation for the empirically confirmed fact that human identity is determined by all influential factors present in the lifeworld. Any theory that neglects any efficient causes for the formation of identity in concrete circumstances of time, space, and culture inevitably fails. The practical value of this article is to create a theoretical foundation for empirical research on natural or artificial transformations of human identity in specific circumstances of cross-cultural communication and competition.

Keywords: identity, society, communication.

\section{Introduction}

Today, the issue of identity is one of the critical interdisciplinary subjects for intellectual culture. It unites various fields of research and is a common discussion platform for all human sciences: social philosophy, psychology, linguistics, psychophysiology, neurosciences, cognitive science, and others. Different disciplines emphasize various aspects of the object under analysis, the complex structure of identity stimulating such a distinction. On the one hand, one self-perception emerges at the junction of one's personal experience. On the other hand, one's social position determines the emergence,

(C) Санкт-Петербургский государственный университет, 2020 
function, and transformation of one's identity. Moreover, one can be aware or unaware of both individual and social causes of the emergence and transformation of one's identity. Therefore, the task of establishing the borders between individual and social beings is rather complicated.

In order to comprehend the complex interaction between individual human beings and social structures, it is vital to distinguish various levels of the human world, from primary social units to countries, nations, alliances, and classes. The concept of identity is a specific tool that can clarify the main principles of interaction between particular human beings and other subjects of activity: other persons and their groups and alliances up to international and cross-cultural communication [1].

However, different disciplines insist on different research strategies and methods; this is why research on identity is far from being unified. The main cause is the absence of an interdisciplinary basis that could provide a common ground for various pieces of research. This article intends to find this common ground within the diversity of methodological strategies to consider the identity concept.

\section{Problem Statement}

The most general definition of the identity concept is the answer to the question, Who are you? [2]. Thus, its first function is to establish a distinction between the subject in question and the rest of the world. Along with this, the temporal continuity of the cognition subject is crucial because of its inner change and the transformation of an individual's identity throughout life. For example, Erik Erikson explained the concept of identity as a permanent reference to one's Self, in contrast to the flow of feelings and perceptions [3]. Although different studies seek reasons for the described individuation process in different fields, it is possible to divide them into two main classes.

The first one begins with the individual and seeks to explain the principles of social being proceeding from the individual human structure of body and mind. Within this approach, identity is often a synonym of self-determination and self-image: human beings try to find themselves within the diversity of images that exist in their perception, memory, and fantasy; they create a model of themselves, thus providing an answer to particular life challenges. Abraham Maslow regarded the need for self-actualization as the third basic human need after physical needs and the need for social security [4]. According to Erich Fromm, it is human nature to search for borders of the Self: animals in the wild do not face the problem of self-identification, while people inevitably have to resolve the task of self-identification in society [5]. Along with this, the tradition of psychoanalysis pays considerable attention to establishing the borders of one's Self and distinguishing it from the Other.

The opposite research strategy gives prior attention to the role of social processes in the emergence and function of identity [6]. For example, George Mead and Charles Cooley supported this method. Although they used the notion of Self instead of identity, these notions can be considered as synonyms within this approach [7]. Later, the notion of identity appeared in the works of Erving Goffman [8] and established a firm association with various versions of the symbolic interactionism research strategy [9]. 


\section{Research Questions}

Various approaches to investigate identity usually tend toward one of the two differing research strategies, which can be called individual-centric and sociocentric. Each of these methods emphasizes particular phenomena of an individual or social being, thus making it possible to explain the emergence of certain types of individual behavior and social structures. Nevertheless, each of them reduces the underlying class of phenomena, which they cannot explain.

The individual-centric strategy reduces the influence of social being on individual mental processes, leading to two possible outcomes:

- the first option is the problem of solipsism, which cannot be solved if an individual mind alone is considered. A good but still ineffective attempt to fulfill this task can be found in Edmund Husserl's Cartesian meditations by [10].

- The second option is the rise of clinical psychiatry seeking to establish particular standards for good and vicious types of human beings according to bodily structure, race, or other physical qualities [11]; the advent of nationalism and racism is just a matter of time in this case.

The sociocentric identity research strategy reduces the facts of human mental states to different types of social interaction. The possible outcomes of such a reduction are the following:

- the first option is the attempt to change human nature in line with some political project, for example, to improve human consciousness by spreading a certain ideology. The collapse of the Soviet Union revealed that the quest for the common good could not neglect individual egoistic intentions.

- the second option is linked to the first one, although its form can be opposite - it is the modern neoliberal project that insists on an absolute volitional choice of the identity content, including gender, race, or anything else. The real freedom of such a choice, especially in the case of children, is a matter of discussion.

\section{Purpose of the Study}

Since both individual-centric and socio-centric strategies have strong and weak sides, it is reasonable to consider them as two extremes in identity research, representing internal or external factors of the origin of identity. Most pieces of research can be methodologically qualified as belonging to one of these two models of cognition. That is why a clear understanding of these two research strategies regarding the emergence and essential features of identity is vital to revealing the opportunities for further research on the identity concept. Along with this, uncovering the foundational principles of identity research could help to find a solution that would incorporate the advantages of both methods.

Thus, the purpose of this study is to summarize the main features of the individualcentric and sociocentric research strategies, to consider the common ground on which both methods can favor the investigation of the identity concept, and to propose a hypothesis of the common ground for these two opposite research methods. 


\section{Research Methods}

This study presents a comparative analysis of various philosophical systems and methods while also tracing their emergence in Western philosophy since the early modern period. Along with this, the achievements of contemporary science are used to illustrate the global trend of identity concept transformation. Achievements of contemporary epistemology and interdisciplinary studies provide a necessary foundation and empirical evidence to summarize the standard features of the considered methods to deal with the identity concept and to propose a way of uniting them on a common ground.

\section{Investigating the identity concept}

In Western philosophy, the concept of identity was raised in the second half of the $20^{\text {th }}$ century by Erik Erikson [2]. However, questioning the content of an individual, I, and the source of its emergence dates back to Western philosophy of the $17^{\text {th }}$ century. This period was marked by the refusal to rely on the authority of religious dogmas, and the study of the essence of the human being became a critical issue for the arising worldview. It is worth starting with the consideration of the well-known philosophy of Rene Descartes as a decisive author of the Modern Era.

\section{Introducing the identity concept}

Descartes did not address the issue of identity in an explicit form, but his anthropological conceptions are crucial for its development and provide a theoretical foundation for an essential part of the identity concept - the idea of Self and distinction between the human mind and body. The external observer perceives human identity as corporal and behavioral continuity, while people themselves are intuitively guided by their psychological continuity. In order to prove the immortality of the soul, Descartes starts with individual inner experience [12]. He established the well-known concept of cogito that using contemporary language can be understood as self-perception or self-awareness. Regardless of its interpretation, cogito is something that the subject of cognition lives through, and one's individual experience is supposed to be the foundation for human identity. As a result, a person cannot dissolve in the outside world's constant flow. This idea was crucial for Descartes because it was coherent with the immortality of the human soul that Descartes sought to prove.

\section{Distinction between Identity and Self}

After Descartes, John Locke considered the interaction between human essence and identity in more detail. He claimed that personal identity is equivalent to the identity of continuous consciousness, but not to the identity of any substance (whether it be material or not): "For the same consciousness being preserved, whether in the same or different substances, the personal identity is preserved" [13]. Thus, Locke rejected the presence of connection between identity and the soul, which was of primary interest for Descartes. Locke argues that, according to religious dogma, the human soul must be immortal, while identity transforms during life. Moreover, it is a fact that some points of a particular iden- 
tity can be shared by many people and even through time; for example, the identity of a citizen of a particular state. Therefore, if the soul is equal to identity, then souls can be transferred and are not unique. This was contrary to Christian dogmas, and, hence, impossible to be claimed.

Another critical point of Locke's philosophy is describing human identity as a source of responsibility. Only in this case, one can be rewarded or punished for one's actions. This particular argument introduces the social being into the consideration of the identity concept. Still, emphasis on responsibility implies the prior role of human inner experience, memory, and the continuity of one's life. Therefore, identity remained in the private sphere, manifesting the individual-centric research method.

\section{Identity as a result of an external effect}

David Hume denied Locke's understanding of identity as the unity of consciousness [14]. According to Hume, a person's identity is constituted not by internal feelings but comes from the outside world: it emerges through reputation, fame, and other social structures. In Hume's approach, one's Self is only a bundle of perceptions and one's selfconsciousness is an impression or even illusion of one's Self concerning one's existence. Human Self is continually being created by the outside world and cannot exist prior to experience: it is a blank slate to be filled correctly. That is why particular qualities of a person are not specified at birth but are formed by upbringing and education. Therefore, human Self or identity is not ontologically autonomous, but it is a focal point of convergence for the flow of experiences and perceptions obtained throughout life. According to this approach, people recognize and create themselves through their activity. It means that cultural space and society are of prior importance in the process of emerging identity. Hume's identity concept is quite similar to the vast majority of modern publications and can be considered as one of the first sociocentric methods.

\section{Identity within moral norms}

Immanuel Kant continued to develop the identity issue. His most well-known ideas fall on the postcritical period and are associated with transcendentalism. However, it would be misleading to qualify his explanation of identity using the same categories. The principles of the transcendental constitution rule the process of perception and reasoning but not personal moral choice. According to Kant, the moral law is universal, but it exists in the sphere of possibility. In order to actualize moral law, one must reach it by oneself and translate it into action [14]. This implies abandoning the passive state of mind and transferring humankind to the state of self-awareness [15]. Thus, identity emerges at the level of practical actions: each person individually actualizes the universal moral law and reaches his or her own identity in practice. Accordingly, practical action provides personalization of the moral principle and allows the subject of cognition to be unique and human. Such an approach takes interpersonal relations into account but investigates them through personal experience. It is well known that the categorical imperative to "act only in accordance with that maxim through which you can at the same time will that it become a universal law" [16; 4, p. 421] can be questioned in the case of self-destructive will; hence, much depends on individual experience and a particular identity structure. 
Moreover, "this conception locates choice within a thoroughly normative context since it conceives of choice as motivated by what the agent takes to be a reason for acting" [17, p. 78]. Thus, Kant's theory assumes human actions to be conscious and transparent to self-cognition. In this case, obtaining knowledge about the actual social structure through introspection is not a problem in principle, and an individual-centric strategy is justified. However, further research revealed many obstacles with this approach.

\section{Transparency of the human inner being}

The concept of identity provided by Kant belongs to classical philosophy; thus, its foundational principle is the transparency of the cognition subject for self-investigation. This implies that there is no critical obstacle for introspection, the cognition of one's Self, and the creation of an identity [18]. Post-Kantian philosophy was developed on the same principles: Georg Hegel introduced the idea of dialectical change; Karl Marx and Friedrich Engels revealed the role of the social basis in the formation of an entire culture. Nevertheless, the idea of the cognition subject remained the same: it is self-transparent and can change its identity after obtaining knowledge. Dialectical materialism assumes a much more complicated interconnection between the social basis and superstructure, however, its detailed analysis is beyond the scope of this paper. In any case, the emergence of revolutionary consciousness still stems from the idea of identity transformation owing to the acquisition of some knowledge; it is a voluntary and conscious transformation of the social reality [see 19]. History shows that such an innate understanding of the cognition subject is alien to the human being. This led to the emergence of nonclassical philosophy, the essential principle of which is a complex structure of the cognition subject [20].

\section{The unconscious: instincts and culture}

Psychoanalysis reveals many cases when the human inner being is nontransparent for self-cognition, which is opposite to the belief of classical philosophy. As a result, the idea of a complex structure of the human inner world aroused further investigation which was focused on the interaction of its components. Sigmund Freud introduced the term Ego to mark the individual center of experience and planning; this Ego is always under the pressure of basic human instincts and social being [21]. The latter is actualized in culture, dictating particular norms of behavior, which are frequently opposite to instincts. Thus, one's identity forms because of the need to realize natural needs within the limits of current culture; one's identity is a compromise between instincts and social norms. This theoretical concept implies two actual identity-forming forces, neither of them being conscious: human instincts are predetermined by bodily organization, while culture is an average amount of environmental circumstances and the collective will. Psychoanalysis focuses on individual human experience and thus reflects the individual-centric research approach. One can claim that the attempt to reveal some archetypes of the collective unconscious [22] actualizes the sociocentric approach and not Jung's particular opinion. However, the fact that these concepts are almost not used beyond the psychoanalytic tradition is indicative. 


\section{Introduction of the identity notion}

Although a clear and well-developed concept of identity is present in Freud's works, it was Erickson, who made it an interdisciplinary notion [23]. Erikson believed that identity develops from the first days of a person's life owing to interaction with the world. The basis of identity is the feeling of being identical to oneself (in fact, this dates back to the ideas of Fichte [24]). Such self-identity emerges regardless of specific circumstances and interaction with other people and exists as a purely logical structure of human consciousness. The social layer is also present, being a result of the experience of how other people recognize the cognition subject. However, it just provides the contents to fill the logical structure of human identity. Thus, this research approach is also consistent with the individual-centric research method.

\section{The symbolic interactionism approach}

Further elaboration of the identity concept is aimed at considering symbols of culture in their mode of existence instead of digging into the individual experience of a specific person. Such an approach is known as symbolic interactionism and remains one of the critical areas of identity studies [2]. Symbolic interactionism considers human identity as a unit of complex interaction between social structures of different levels [25]. George Mead was one of the founders of the symbolic interactionism research strategy. Although Mead used the notion of Self, it can be treated as a synonym of identity in this case [26]. Mead considered the need for self-expression as a primary intention that makes a person perform certain actions in society. The various feedback from society constitutes a particular image of the cognition subject, which is subsequently internalized. At the first stage, identity is affected by personal views of other people. For example, a child has a clear idea of what each of the parents requires from him or her. At the second stage, identity is affected by paradigms of a social group (in Mead's terminology - the generalized other). The symbolic interactionist approach is often criticized because of its insufficient attention to sociocultural and historical aspects, resulting in examining the behavior of an individual as if in a vacuum - or just in the context of local interactions. Along with this, a significant challenge is the question of how the symbols of culture become available in their pure form and avoid the influence of a person's mind.

\section{The world's a stage: complex identity}

Contemporary research of the identity concept should take into account the transformation of the human world caused by technological progress and global communication. Today, an individual has to combine a growing number of social roles; social life requires that a person be considerate towards the expectations of others [27]. Erving Goffman tried to describe the complex structure of the contemporary situation: he developed Mead's ideas in the concept of social drama and concentrated on the techniques of self-expression and the creation of the impression of Self [28]. Goffman elaborates on Shakespeare's metaphor from Jaques to Duke Senior "All the world's a stage, and all the men and women merely players; They have their exits and their entrances; And one man in his time plays many parts". Goffman pays special attention to the idea of separation of public and per- 
sonal Selves. He claims that in the presence of other people, public Self is applied, while with close relatives one is hidden backstage - so the need for the manifestation of public Self disappears and it becomes possible to discover the real face. Such a separation of stage and backstage does not mean distinguishing true and false Selves, but it proves that an individual presents different aspects of his or her Self depending on the society they interact with. The online world provides a good example of editing the facets of Self practice [29]. Distancing from one's social role makes it possible to maintain one's individuality because any person is more than what is prescribed by a particular society role. Identity is a concept designed to unite all the units together. This idea belongs to the sociocentric approach.

\section{The temporal aspect of the identity concept}

Along with the spatial diversity of different social roles, any human being exists in time and lives through various life events. Since Descartes, this aspect has been recognized as an important philosophical problem; however, most authors considered the human inner Self as something that preserves continuance in a flow of change (perhaps, Locke was among the few who insisted on the distinction between Self and eternal essence). Within the above-described theory of Goffman, identity is also considered as a focal point that provides coherence for various patterns of action. However, human identity is a part of reality. Therefore, it cannot avoid the effect of the environment, other people, social structures, and so on: it inevitably changes. Vittorio Hösle described this process and illuminated the essential role of identity crisis in the process of a person's evolution and maturing [30]. Transformation and adaptation of identity are impossible without creating an image of oneself, its elaboration, and throwing away when needed ${ }^{1}$. Moreover, these processes are not only essential to the transformation of a particular individual but are also manifested in the history of social groups and cultures, which exist long enough and can cope with arising challenges [32].

\section{Identity crisis and social being}

The essential knowledge revealed by studies on identity crisis is an essential interconnection between social and personal being. An Identity crisis can be a result of personal reasons (for example, aging or the inability to reach success) and can happen even to a hermit. Nevertheless, a person excluded from society has no source from which he or she can obtain material to form his or her new identity. Rom Harré in his Personal being tried to reveal the complexity of the identity emergence process and numerous social interconnections involved in it [33]. As a result, it is unlikely that a sole individual can overcome an identity crisis. Although many mystical and religious doctrines argue for a way of leaving the human world, they recognize that one who can do this is not a human being anymore. Therefore, studies that consider the identity crisis and overcoming it, cannot neglect the role of society; hence, they belong to the sociocentric approach.

${ }^{1}$ Thus, the fashion to overprotect individuals against various psychological traumas goes against the natural process of becoming a mature person. Yet it is of little surprise since the creation of the snowflake generation image benefits today's global market [31]. 


\section{The contemporary situation}

\section{Exploring the human brain}

Many theoretical systems considered above focus on the investigation of the individual. Although no theory can deny the effect of the social being, the general predisposition is that individual experience is enough to produce human identity, at least as a logical structure. Contemporary cognitive science replicates this approach because it believes that the investigation of the structure of the human brain is enough to reveal all essential principles of the functioning of human consciousness [34]. Even if consciousness is considered as an illusion [35] or a methodological tool to predict complicated behavior [36], or if the human Self appears after uniting the stories into one narrative [37], the object of research is individual experience. The fact that cognitive science provides experiments on a mass of subjects has an insignificant effect because in any particular case, it is a particular isolated brain that is investigated. The generalization of experimental data, including big data computing, hides the researcher's predisposition behind complicated procedures. One of the most important but hidden ideas resembles Hume's opinion that external effects create one's identity. Attention to inborn body structures like genes does not change anything because all these factors are external to what we call our "I". Identity is inscribed not on a blank slate, but on one with a prescribed pattern. However, does it make any difference?

Thus, various types of cognitive science also represent individual-centric research of human identity. The crucial role of the human brain and other bodily structures is an argument to use the notion of an individual-centric approach instead of the psychocentric one.

\section{Creating genders and social roles}

Sociocentric studies emphasize the role of the Other in the formation of personal identity. The Other can be represented by a person, by a group of people, and by a generalized culture with which the cognition subject interacts. In the course of active interaction with society, a person becomes aware of the features that distinguish him or her from other people and defines his or her identity using detected boundaries. Thus, an individual is interlaced with social values or symbols. Accepting and rejecting these symbols creates a unique contour of personal identity. The meaningful difference from the individual-centric approach is the claim that people have no identity beyond social being. Therefore, one can fully voluntarily choose an identity, including gender, race, or whatever they prefer. This is a complete reproduction of the classical philosophical belief that one's consciousness has no boundaries with the body, culture, and other facts, the acknowledgement of which is supposed to be an achievement of modern science. Since the latter is a vital part of the modern discourse, such ideas are self-contradictory.

\section{The active realism approach}

All the above theories illuminate particular features of the origin and functioning of human identity. The theories differ because different facts within a person's life are emphasized. This review illuminates how the identity concept transformed during the short but 
intensive period of Western history: obviously, the lifeworld of Descartes is different from that of Goffman or Hösle ${ }^{2}$. Since the human body cannot transform biologically within a period of several centuries, it is the transformation of culture that comes to the fore.

The contemporary theory of knowledge provides a theoretical foundation for the following viewpoint: the act of perception is the foundation of individual experience, and perception is an active interaction of a person with the environment [39]. Both human body and human mind are involved in the active process of the environment's transformation [40], and the possibility to explore and discover the new is a criterion of real experience [41]. Thus, the process of individuation is determined by real factors of a particular human experience.

Michael Gazzaniga claims that the aspiration to possess consciousness is a human instinct, although it is not completely automatic because the symbols that we use are complementary and ambiguous [42]. Human identity, being a high-level structure of consciousness, is definitely the same. A recent UCLA experiment by Marco Iacoboni provides interesting data: the participants were to identify pictures of themselves among others and failed to do this when the right angular gyrus of the volunteer's brain was disabled by the transcranial magnet [43]. The authors suggest that the human Self cannot be located in some particular area of the brain, but it is a symbol that represents the totality of one's body structure. There are a large range of possible modifications for an individual's identity. Until it becomes possible to change the body completely, unchangeable predispositions will continue to determine the foundation of "Who you are".

\section{Discussion}

The human body is a necessary tool that provides possibilities to interact with the real world; hence, most natural and social affordances are prescribed by one's own body and not beliefs. One's beliefs are due to a particular social interaction that provides for the actualization of possibilities. Therefore, it is impossible to separate social being from the individual sphere. Both social and individual spheres comprise possibilities of interaction within which people obtain their identity.

The provided investigation has revealed that identity is not an individual or social structure, but it is a result of their interaction. This interaction occurs in the form of image or symbolic reflection: an individual translates his or her desired image to society and receives feedback from it. Society suggests various responses: the broader one's possibilities to interact with the world, the more various the social feedback is. One's task is to find an invariant among all the received images. This invariant is the answer to the question, "Who are you?"

It appears that the answer of contemporary science is that human identity cannot be separated from the totality of the human lifeworld. Being doomed by one's body is a mistake, neglecting one's body is a mistake as well. When one wants to change their identity, a simple choice is not enough; the process of a real transformation is required. This resembles the ideas of Alfred Whitehead [44] that an actual entity is a process. The recent World Congress of Philosophy took place in Beijing, August 2018 and its theme can be translated as "Learning to Be Human" - because there is nothing like being human, one can only

${ }^{2}$ Edmund Husserl introduced the notion of lifeworld in The Crisis of European sciences and transcendental phenomenology [38]. 
constantly become human. This is coherent with the Chinese view on the issue of identity, which cannot be covered in such a short article.

We can even suggest deepening the question or answer provided above. If one's identity or Self is the sum of one's actions [40-43], the totality of one's lifeworld cannot be really separated from the world itself. Is it possible to separate the structure of one's body from all the things that one has got from one's family, received with food or another experience, from the rain or sunlight? Is it possible to distinguish between one's beliefs and the things that one was told or one's achievements? As long as there are no criteria, is there any You except the world?

\section{References}

1. Hughes, C. (2002), Social philosophy today - Race, social identity, and human dignity - Introduction: Attending to differences, in Race, Social Identity, and Human Dignity, Charlottesville, Va: Philosophy Documentation Center, pp. 1-8.

2. Schwartz, S. J., Luyckx, K. and Vignoles, V.L. (2011), Handbook of identity theory and research, New York: Springer Science+Business Media.

3. Erikson, E. H. (1980), Identity and the life cycle, New York: Norton.

4. Maslow, A. H. (1966), Self-actualization, Big Sur Recordings: n. p.

5. Fromm, E. (1955), The sane society, Greenwich, Conn.: Fawcett Publications.

6. McGarty, C. and Haslam, S. A. (1997), The message of social psychology: perspectives on mind in society, Cambridge, Mass.: Blackwell Publishers.

7. Leary, M. R. and Tangney, J.P. (2012), Handbook of self and identity, New York and London: Guilford Press.

8. Goffman, E. (1963), Stigma; notes on the management of spoiled identity, Englewood Cliffs, N. J.: Prentice-Hall.

9. Stryker, S. (1980), Symbolic interactionism: a social structural version, in Benjamin/Cummings series in contemporary sociology, Menlo Park, Calif.: Benjamin/Cummings Publ. Co., pp. 15-65.

10. Husserl, E. (1977), Cartesian meditations: an introduction to phenomenology, The Hague: M. Nijhoff.

11. Lombroso, C., Gibson, M. and Rafter, N.H. (2006), Criminal man, Durham, NC: Duke University Press.

12. Descartes, R. (2012), Meditations on first philosophy: in which the existence of god and immortality of the soul are demonstrated, Arlington, VA: Richer Resources Publications.

13. Locke, J. (1956), An essay concerning human understanding, Chicago: Gateway Editions (A Gateway edition, vol. 6016).

14. Hume, D. (2003), A treatise of human nature, Mineola, New York: Dover Publications (Dover philosophical classics).

15. Kant, I. and Bernard, J.H. (2005), Critique of judgment, New York: Barnes \& Noble Books.

16. Kant, I. (1902), Gesammelte Schriften, vol. 25, pt. 1, Berlin: G. Reimer.

17. Reath, A. (2006), Agency and autonomy in Kant's moral theory, Oxford and New York: Clarendon Press, Oxford University Press.

18. Lektorsky, V.A. (2018), Is Our Idea of the Subjective World an Illusion?, Russian Studies in Philosophy, vol. 56, pt. 1, pp. 6-17.

19. Rockmore, T. (2015), Hegelian Interpretations of Marx, Symposium-Canadian Journal of Continental Philosophy, vol. 19 (2), pp. 212-232.

20. Lektorsky, V.A. (2012), Rationality as a Value of Culture, Voprosy filosofi, no. 5, pp. 26-35. (In Russian)

21. Freud, S. (1955), The interpretation of dreams, New York: Basic Books.

22. Jung, C. G. (1980), The archetypes and the collective unconscious, in The collected works of C. G. Jung, vol. 9, pt. 1, Princeton, N. J.: Princeton University Press.

23. Erikson, E. H. (1968), Identity, youth, and crisis, New York: W. W. Norton.

24. Karasek, J. (2016), I and Not-I On the pure Structure of the World as Picture in Fichte, in Bild, Selbstbewusstsein, Einbildung, Leiden: Brill, pp. 77-94.

25. Cooley, C.H. (1912), Human nature and the social order, New York: C. Scribner's sons.

26. Mead, G. H., Morris, C. W., Huebner, D. R. and Joas, H. (2015), Mind, self, and society, Chicago; London: University of Chicago Press. 
27. Berger, P. L. and Luckmann, T. (1990), The social construction of reality: a treatise in the sociology of knowledge, New York: Anchor Books.

28. Goffman, E. (1969), The presentation of self in everyday life, London: Allen Lane.

29. Bullingham, L. and Vasconcelos, A. C. (2013), 'The presentation of self in the online world': Goffman and the study of online identities, Journal of Information Science, no. 39 (1), pp. 101-112. sian)

30. Hösle, V. (1994), Personal and Social Identity Crisis, Voprosy filosofii, no. 10, pp. 112-123. (In Rus-

31. Smith, A. N. (2019), Pursuing "Generation Snowflake": Mr. Robot and the USA Network's Mission for Millennials, Television \& New Media, vol. 20, iss. 5, pp. 443-459.

32. Toynbee, A. and Somervell, D. C. (1947), A study of history, New York: Oxford University Press.

33. Harré, R. (1984), Personal being: a theory for individual psychology, Cambridge, Mass.: Harvard University Press.

34. Fodor, J. A. and Fodor, J. A. (2008), LOT 2: The language of thought revisited, Oxford and New York: Clarendon Press, Oxford University Press.

35. Ryle, G. (2009), The concept of mind, New York and London: Routledge.

36. Dennett, D. C. (1987), The intentional stance, Cambridge, Mass.: MIT Press.

37. Dennett, D. C. (1991), Consciousness explained, Boston: Little, Brown and Co.

38. Husserl, E. (1970), The crisis of European sciences and transcendental phenomenology; an introduction to phenomenological philosophy, in Northwestern University Studies in phenomenology \& existential philosophy, Evanston: Northwestern University Press.

39. Gibson, J. J. (1979), The ecological approach to visual perception, Boston: Houghton Mifflin.

40. Lenk, H. (2003), Grasping reality: an interpretation-realistic epistemology, World Scientific: River Edge, N. J. (Series on the foundations of natural science and technology, vol. 5).

41. Lektorsky, V.A. (2017), Cognition, Action, Reality, Voprosy filosofii, no. 9, pp. 5-23. (In Russian)

42. Gazzaniga, M.S. (2018), The consciousness instinct: unraveling the mystery of how the brain makes the mind, New York: Farrar, Straus and Giroux.

43. Blakeslee, S. and Blakeslee, M. (2007), The body has a mind of its own: how body maps in your brain help you do (almost) everything better, New York: Random House.

44. Whitehead, A. N. (1978), Process and Reality, New York: The Free Press.

Received: March 20, 2020

Accepted: September 23, 2020

Authors' information:

Ella D.Dryaeva — PhD in Philosophy, Associate Professor; dryaeva.ella@gmail.com

Ilya A.Kanaev — PhD in Philosophy, Postdoctor; kanaev@qq.com

\title{
Индивидуальные и социальные условия формирования идентичности: сравнительный анализ исследовательских стратегий
}

\author{
Э. Д. Дряева ${ }^{1}$, И. А. Канаев ${ }^{2}$
}

${ }^{1}$ Московский государственный университет им. М. В. Ломоносова, Российская Федерация, 119991, Москва, Ленинские горы, 1

2 Университет Сунь Ятсена,

Китайская Народная Республика, 510275, Гуанчжоу, Синган Си, 135

Для цитирования: Dryaeva E. D., Kanaev I. A. Individual and social determinants for the formation of identity: A comparative analysis of research strategies // Вестник Санкт-Петербургского университета. Философия и конфликтология. 2020. Т. 36. Вып. 4. С. 621-633.

https://doi.org/10.21638/spbu17.2020.402

Статья посвящена изучению понятия идентичности. Задача исследования - выявление принципов, на основании которых могут быть объединены различные подходы к описанию возникновения и трансформации человеческой идентичности. Метод ис- 
следования - сравнительный анализ значимых теорий западной философии с точки зрения достижений современных междисциплинарных исследований. Исследование понятия идентичности начинается с анализа взглядов Декарта, далее прослеживаются историческая преемственность и трансформация этого понятия в работах Локка, Юма, Канта, Фрейда, Эриксона, Мида, Хоффмана, Харре, Хёсле и др. В зависимости от выбранной стратегии рассмотрения философские системы можно разделить на индивидуально-центристские и социоцентристские программы исследования. Тем не менее ни один из подходов не способен осуществить полную редукцию социального к индивидуальному или же индивидуального к социальному. Поэтому разделение исследовательских стратегий является сугубо методологическим. Невозможность полностью редуцировать социальное к индивидуальному или же индивидуальное к социальному обусловлена тем, что обе эти сферы являются действующими причинами формирования и трансформации идентичности человека. Поэтому идентичность человека должна рассматриваться как результат взаимодействия сферы индивидуального и социального. На основании достижений современной теории познания, оформляемых в теоретическую систему В.А. Лекторским, Г. Ленком, Э. Агацци и др., закладывается фундамент для объяснения идентичности как результата активной деятельности субъекта познания. Таким образом, проведенное исследование раскрывает теоретическое обоснование подтверждаемого опытом факта - идентичность человека определяется всеми реально воздействующими факторами, которые присутствуют в жизненном мире человека. Любая теория, которая пренебрегает какими-либо действующими причинами формирования идентичности человека в данных конкретных условиях пространства, времени и культуры, неизбежно окажется несостоятельной. Практическая значимость данного исследования заключается в создании теоретической базы для эмпирического изучения стихийного или сознательного изменения идентичности человека в конкретных условиях межкультурной коммуникации и соперничества.

Ключевые слова: идентичность, общество, коммуникация.

Статья поступила в редакцию 20 марта 2020 г.; рекомендована в печать 23 сентября 2020 г.

Контактная информация:

Дряева Элла Давидовна - канд. филос. наук, доц.; dryaeva.ella@gmail.com Канаев Илья Александрович - канд. филос. наук, постдоктор; kanaev@qq.com 